УДК $639.3(4-11)(091)$

(C) 2015

Бондаренко О. М., кандидат сільськогосподарських наук

Полтавська державна аграрна академія

\title{
З ІСТОРІї РОЗВИТКУ СКОТАРСТВА НА ПОЛТАВЩИНІ (КІНЕЦЬ ХІХ - ПОЧАТОК ХХ СТОЛІТТЯ)
}

\author{
Рецензент - доктор сільськогосподарських наук, професор А. А. Поліщук
}

\begin{abstract}
На основі літературних першоджерел розглядаються окремі аспекти з історії розвитку скотарства на Полтавщчині в кінці XIX - на початку XX століть. На розведення великої рогатої худоби особливий вплив мали два фактори - збільшення чисельності міського населення й інтенсифікаџія обробітку землі. Ріст товарного землеробства, щзо вимагав підвищення продуктивності праці, приводив, з одного боку, до більш посиленого розведення робочої худоби, ніж продуктивної, а з іншого, внаслідок розшарування на селі, - до росту поголів'я лише в заможної частини селянства, щзо мала тяглову силу. Для Полтавщчини розведення великої рогатої худоби на усіх етапах історичного розвитку відігравало вкрай важливе значення, забезпечуючи населення висококалорійною м'ясо-молочною продукиією.
\end{abstract}

Ключові слова: Полтавська губернія, велика рогата худоба (воли і корови), сіра украӥнська порода, основна господарська тяглова сила, власнищькі економії, поміщицькі господарства.

Постановка проблеми. 3 давніх-давен Полтавщина, яка славилася своїми природними багатствами мала добре розвинуте тваринництво.

Тваринництво належить до важливих господарських занять, які існували в Україні. Хліборобство не могло успішно розвиватись, якби не були приручені тварини, що забезпечували мешканців нашого краю молочними і м'ясними продуктами, використовувались як тяглова сила. Добрий урожай отримували тоді, коли для посіву був якісно підготовлений грунт. Для основної маси населення Полтавщини велика рогата худоба (воли і корови) відігравала набагато більше значення, ніж коні. Без відповідних упряжних знарядь для ефективного застосування у господарстві тяглової сили цього досягти неможливо.

Згідно статистичних даних за 1845 рік загальна чисельність великої рогатої худоби складала 782210 голів, тоді як коней було у 3,5 рази менше - 224951 голів. Велика рогата худоба, особливо воли, слугували перш за все робочою силою у селянських господарствах, для цього нерідко використовували і корів, яких називали «яремними». 3 метою отримання молочних продуктів селяни здебільшого утримували корів лише у розмірах домашніх потреб. Розводили, як правило, велику рогату худобу сірої української породи, що відзначалася високою працездатністю, витривалістю, була міцного складу. 3 кінця XIX ст. все більше спостерігається прагнення населення замінити волів кіньми. Це пояснюється, 3 одного боку, прогресуючим скороченням: погіршенням кормових площ унаслідок розширення посівів, збільшенням кількості населення; 3 другого - слабким розвитком посівів трав, порівняно з минулими роками, все більшим розорюванням грунтів, цілинних земель. Унаслідок цього кінь ставав усе більш вигідним економічно, не говорячи вже про такі другорядні причини, як непридатність волів для візницького промислу в зимовий час, тоді як добре підковані коні були взимку незамінними $[10,11,12]$.

Аналіз останніх досліджень і публікацій, у яких започатковано розв'язання проблеми. Починаючи з кінця XIX ст., Полтавське губернське земство організувало щорічне видання таких цінних для краєзнавців збірників, як «Статистичний довідник Полтавської губернії на... рік» та «Статистичний щорічник Полтавського губернського земства». У цих збірниках вміщено аналітичні матеріали щодо різних аспектів економічного і культурного життя мешканців Полтавщини. Певним чином відображено у цих збірниках i тваринництво, матеріали про яке подавалися в узагальненому вигляді після відповідних подвірних переписів. Нерідко публікувалися зведені дані кількох подвірних переписів із відповідними коментарями $[10,11,12]$.

Цінним джерелом із питання, що нас цікавить, $€$ історіографічний огляд журналів «Хуторянин» i «Вестник южно-русского животноводства», а також організоване у 1909 видання редакцією журнала «Хуторянин» збірника під назвою "Календарь «Хуторянина» (Сборник сельскохозяйственных статей)», шість випусків якого побачило світ до 1917 року. Перший із вищезгаданих журналів виходив у Полтаві 31896 по 1917 роки. Влітку видавався двічі на місяць, а в інші пори року - щотижня. «Вестник южнорусского животноводства» був спеціалізованим 


\section{СІЛЬСЬКЕ ГОСПОДАРСТВО. ТВАРИННИЦТВО}

журналом, який із 1908 по 1916 роки виходив у Полтаві тричі на місяць під егідою того ж таки сільськогосподарського товариства $[1,2,13]$.

Мета публікації - узагальнити дані, що стосуються становлення та розвитку скотарства на Полтавщині в кінці XIX - на початку XX століть.

Результати дослідження. Детальну характеристику порід великої рогатої худоби і особливості ii використання у селянських господарствах знаходимо у «Военно-статистическом обозрении Российской империи». «Усі три губернії, писали чиновники Генерального штабу, - Харківська, Чернігівська і Полтавська мають у своєму розпорядженні найрізноманітніші породи рогатої худоби. В одному і тому ж місці можна бачити хорошу худобу і поруч 3 нею - дрібних, слабких і виснажених тварин, про які важко сказати, для чого вони придатні. Худоба такої якості раніше дуже рідко зустрічалася у центральній Україні, але тепер і тут її стало досить багато. В Україні існують дві хороші породи рогатої худоби: черкаська, або угорська, і українська, або валахська. Ці дві породи досить легко розрізнити не тільки за зовнішнім виглядом, але і за їх внутрішньою якістю: бик черкаський при своїй великій масі, неповороткий, незграбний і тихого норову; бик український красивого середнього зросту, дуже швидкий, сильний із диким поглядом. У жодному селянському господарстві, - продовжують далі опис великої рогатої худоби автори згаданого «обозрения», - немає такої чудової худоби, яка зустрічається на хуторах. Рогата худоба складає тут головну цінність.

Волами хуторяни обробляють землю. Сіру українську худобу вони відгодовують і продають, а одержаний гній використовується як добриво під городні культури, конопляники і поля. Молочними продуктами харчується родина. Проте найбільшу вигоду рогата худоба приносить у випадку використання іiі для транспортування вантажів. Багато хуторян мають від 10 до 20 пар волів, 3 якими вони ходять до Криму або Азовського моря, де купують на свій капітал або за підрядом сіль і рибу, розвозячи товар по різних місцевостях України» [6].

У результаті надмірного розорювання сільськогосподарських угідь після скасування кріпацтва умови для утримування великої рогатої худоби, як і тваринництва в цілому, на Полтавщині суттєво змінилися. Згідно з даними «Сборника статистических сведений о Полтавской губернии» у 1866 році на Полтавщині нараховувалося 767464 голови великої рогатої худоби. Найбільшу ії кількість мали мешканці таких міст, як Лохвиця (1915 голів), Полтава (1849), Кременчук (1722), Миргород (1490), Градизьк (1317) та Переяслав (1216). Із повітів перше місце посідає Золотоніський 79564 голови. Наступні місця належали Костянтиноградському (67200 голів), Гадяцькому (63987), Пирятинському (60063) і Полтавському (59439). Якщо взяти за основу середні показники, то на кожне місто припадало 1034 голови великої рогатої худоби, а на кожен повіт - 49998 [2, 8].

До 1883 року основну масу селянської худоби складали воли, з роками їх питома вага зменшувалась. Так, у 1883 році питома вага волів у селян складала 28,9\%, корів 24,7 \%, бугаїв 0,2 \%. Перепис 1900 року дав такі показники: волів $22,7 \%$, корів - 35,1\%. Бугаїв ця статистика зовсім не зафіксувала $[8,13]$.

Основною господарською тягловою силою в Україні до початку XIX ст. залишався віл. Документи XVI-XVII ст. свідчать, що у селах Полтавщини була майже однакова кількість волів і коней, однак у плуг запрягали переважно волів. У другій половині XIX ст. поголів'я волів різко зменшилось - унаслідок аграрної реформи 1861 р., коли селяни стали масово полишати землю. Так, на Полтавщині у с. Опішня в 1835-1882 pр. кількість волів зменшилась від 108 до 40, а коней збільшилась від 15 до 37. Це було характерно для усієї етнічної території $[5,9]$.

Основними постачальниками сільськогосподарської продукції були великі власницькі економії.

Турбуючись про розвиток сільського господарства на Полтавщині, Полтавське сільськогосподарське товариство, яке було започатковано у 1865 році за ініціативою князя С. В. Кочубея, досить конкретно і плідно займалось питанням розвитку тваринництва. Значна увага була приділена і розвитку скотарства. За ініціативою товариства було створені парувальні пункти, організовано виставки тварин.

В окремих великих поміщицьких господарствах Полтавщини наприкінці XIX - на початку XX ст. тваринництво знаходилося на досить високому рівні. Існували хороші, нерідко взірцеві заводи: ферми великої рогатої худоби, коней, овець, свиней, домашньої птиці. Наприклад, Карлівський маєток (тоді Костянтиноградського повіту, тепер місто Карлівка - райцентр Полтавської обл.) нащадків великої княгині Олени Павлівни (невістки імператора Павла I). Загальна площа маєтку після селянської реформи 1861 року й аж до Жовтневої революції 1917 року становила понад 58 тисяч десятин. У господарстві було високо розвинене тваринництво: кінний завод, де вирощували арабських коней та коней верхової кірасирської породи, завод великої рогатої худо- 


\section{СІЛЬСЬКЕ ГОСПОДАРСТВО. ТВАРИННИЦТВО}

би - української, симентальської, волоської порід та інші тварини. Робочих коней у Карлівській економії налічувалося близько 1800, а волів майже 3700 голів. Тож економічні поля чудово удобрювалися перегноєм із ферм і була достатня кількість робочої худоби для обробітку полів [ 9].

У Полтавському повіті були великі зразкові економії князя В.С. Кочубея у Диканьці та в Жуках. Так, у Диканській економії (в межах маєтку) площею 3860 десятин земельних угідь, велася покращена зернова система польового господарства, а частина землі пускалася у залежності від росту трав. Було тут і високорентабельне тваринництво: завод напівкровних англійських коней, молочна худоба симентальської породи та помісь із місцевими, вівці - каракулі, а також свині - беркшири і темворси. Верст за 6 на північний захід від села Яківці (нині околиця Полтави), коло річки Кас'янова Балка, знаходилася Жуківська економія князя В. С. Кочубея, де було 2785 десятин земельних угідь. Це теж було одне 3 взірцевих господарств губернії. Сівозміна на ближніх ділянках на полях тут запроваджувалася восьмипільна, а на більш віддалених - частково трипільна та перелогова. 31868 року в економії існував завод арденських коней, була велика рогата худоба - гібрид симентальської породи, а також свині - беркшири $[6,9]$.

В межах села Ковалівка Полтавського повіту був розташований маєток нащадка одного з найбагатших полтавських німців-колоністів В. В. Трепке «Ковалівка» площею 1150 десятин. Окрім високорентабельного зернового i зернопереробного господарства, тут було добре розвинено тваринництво. Особливо славився кінний завод: матки напівкровні і на три чверті кровні арденки, яких злучали 3 жеребцями арденами, клейдесдалем та рисаками (каретні коні) [9]. У селі Парасковіївка того ж Полтавського повіту (нині с. Куликове Полтавського району) був маєток другого з братівнімців, які народилися на Україні - Е. В. Трепке. На високому рівні було тваринництво: завод робочих коней - помісі арденських і клейдесдальських, велика рогата худоба - гібрид симентальської породи, вівці - помісі каракульських порід, свині - гібрид місцевих із беркширами $[9,10]$.

На лівому березі річки Супій, біля села Згурівка Прилуцького повіту Полтавської губернії (тепер Згурівка - райцентр Київської обл.) знаходився чудовий маєток із тією ж назвою, що й село, площею понад 19 тис. десятин земельних угідь - власність князя В. П. Кочубея. У цьому маєтку зразково було поставлено скотарство зі спеціальними заводами - помісі місцевої породи 3 шароле [6, 12].
Біля річки Сухий Омельничок, у містечку Пустовійтове Кременчуцького повіту (тепер село Глобинського району), наприкінці XIX - на початку XX ст. знаходився маєток поміщика В. О. Остроградського «Пустовійтове» площею близько 3 тис. десятин земельних угідь, де велася трипільна сівозміна. У господарстві був кінний завод рисистих коней, завод великої рогатої худоби української сірої породи, а також свині чистокровні лінкольни [10].

А за 4 версти на схід від містечка Пустовійтове розташовувався маєток сестер-графинь О. В. та М. В. Капніст «Пузикове», біля однойменного села (тепер с. Пузикове Глобинського району), 3 площею земельних угідь 2780 десятин, де запроваджувалася семипільна і шестипільна сівозміни. Тваринництво теж було на належному рівні: завод коней верхової породи, велика рогата худоба - гібрид симентальської породи з місцевою, вівці - каракулі чисельністю до 400 голів, свині - беркшири [9]. У цьому ж повіті, верст за 6 на південний схід від залізничної станції Рублівка, був маєток поміщиці Є. М. Петроградської «Писарщина» із загальною площею земельних угідь понад 1700 десятин. Велика рогата худоба в маєтку була виведена $з$ господарств німецьких колоністів Таврійської губернії $[6,11]$.

Далі вздовж залізниці, на 18-й версті за Рублівкою, станція Глобино, а поруч однойменне містечко (тепер м. Глобино - райцентр Полтавської обл.). Тут знаходився маєток М. О. Шапошникова площею в 1650 десятин, який на час звільнення селян 3 кріпацтва належав багатим дворянам Магденкам, котрі володіли тут понад 10000 десятин земельних угідь. У господарстві Шапошникова була прийнята шестипільна сівозміна. У маєтку утримували коней робочої породи, українських волів, велику рогату худобу симентальської та української порід, свиней - беркширів і темворсів $[6,8]$.

Верст за 8 на північний схід від станції Рублівка знаходився маєток поміщика О. К. Панайотова «Обознівка», поблизу однойменного волосного містечка (тепер с. Обознівка Глобинського району), площею 1540 десятин із високою культурою виробництва, де запроваджувалися різні багатопільні сівозміни. Молочне стадо тут складалося 3 напівкровних швейцарських і місцевих корів, вирощувалися свині - йоркшири і помісь із місцевими, вівці - каракулі, коні - напівкровні та місцеві. Була також велика племінна птахоферма $[5,6]$.

За 10 верст на схід від містечка Келеберда, поблизу невеликого волосного села Бригадирівка 3 населенням близько 500 чоловік, був маєток спадкоємців 3. Т. Тараня «Григоро-Бригадирівка» Кобеляцького повіту (тепер село Кобеляцького 


\section{СІЛЬСЬКЕ ГОСПОДАРСТВО. ТВАРИННИЦТВО}

району) площею близько 750 десятин, у тому числі 500 десятин орних земель. Тут були добре налагоджена зернова система й високорозвинене тваринництво: завод робочих і запряжних коней у кількості 20 кобил і 2 жеребці, велика рогата худоба - місцевої породи, вівці смушкові - помісь каракулів із решетилівськими і сокільськими, свині - беркшири [8].

У Хорольському повіті, біля містечка Оболонь (тепер село Семенівського району), на час відміни кріпосного права був великий однойменний маєток, що належав колишньому статс-секретареві М. П. Позену, який мав тут 13200 десятин земельних угідь. Із 70-х років XIX ст. і до початку XX ст. маєток, де залишилося 2900 десятин, належав його синові Л. М. Позену. Маєток був одним із кращих у повіті. Польове господарство тут велося за трипільною системою сівозмін. Окрім основних хлібних культур сіяли просо, льон, багаторічні трави. На час перепису (10-ї ревізії) 1859 року тут були кінний, винокурний та селітряний заводи; на початок XX ст. - завод робочих коней - чистокровні ардени, напівкровні англо-арабські, велика рогата худоба - молочна симентальсько-фрейбурзької породи, а робоча - чистокровна українська, свині - чистокровні беркшири, гуси - гергелі. Другим за розмірами у цьому ж повіті на початку XX ст. був маєток Є. О. Базилевської в містечку Остап'є (нині село Вєликобагачансього району) площею понад 1600 десятин. Характер маєтку був суто землеробський із перевагою польових культур. Проте й тваринництво розвивалося на належному рівні. Молочна худоба в економії $€$. О. Базилевської була німецька, а частково - сіра українська. Був невеликий кінний завод. Вирощували також свиней - беркширів. Однак особливої уваги у господарстві надавалося птахівництву. Щорічний приплід птиці становив 900 голів, із числа яких перше місце займали гуси, друге - індики $[6,12]$.

Верст за 6 на південний захід від Хильківки знаходився маєток «Бурбине» (нині село Пузирівської сільради Семенівського району) М. М. Устимовича площею 1000 десятин. У господарстві знаходився хороший кінний завод напівкровних англійських, чистокровних арабських, орловсько-ростопчинських і рисистих порід; щорічно продавали близько 30 голів коней. 3 великої рогатої худоби утримувалася і вирощувалася чистокровна українська і симентальська, а також вівці - каракулі, свині - чистокровні йоркшири $[6,9]$.

Не можна не згадати і великий взірцевий маєток князя М. В. Рєпніна (онука малоросійського генерал-губернатора, князя М. Г. Рєпніна-Волкон- ського) у волосному містечку Яготин Пирятинського повіту (тепер райцентр Київської обл.) площею понад 9 тис. десятин. У господарстві було запроваджено дві сівозміни: одна поблизу садиб - восьмипільна, а друга - дванадцятипільна, на віддалених полях. У маєтку діяв кінний завод, де розводили напівкровних англійських коней і робочих напівкровних - першеронів. Належним чином було поставлено скотарство і птахівництво. Із 1883 року розводили каракульських овець: стадо решетилівської породи місцевих овець злучали 3 чистокровним бухарськими баранами $[6,8]$.

Iз середини XIX ст. до 1914 р. на українських землях тваринництво було нерозривно пов'язане 3 хліборобством. Цей зв'язок відповідав певній системі обробітку грунту. За перелоговою - для худоби було достатньо кормів, тому утримували іiі у великій кількості. 3 переходом до трипільної системи рівновага між цими двома галузями сільського господарства порушилася. Кормова база для свійської худоби скоротилася, а разом із тим стало менше й тварин. Обробити землю було складно, бо бракувало як робочих тварин, так $\mathrm{i}$ гною, знижувалась урожайність і розвиток сільського господарства гальмувався [7].

Упродовж 1890 року селяни усіх повітів Полтавщини не могли обійтися своїми пасовищами, наймаючи їх у великих землевласників або віддаючи худобу на випас за певну плату. У більш сприятливих умовах знаходилися селяни Прилуцького, Роменського і частково Лохвицького повітів. У Костяниноградському, Пирятинському, Хорольському повітах пасовища найчастіше винаймали.

По окремих повітах Полтавщини розходження щодо кормових угідь були досить суттєвими від 85814 десятин у Переяславському повіті до 20219 десятин у Зіньківському. Загалом по губернії у 1889 році земські статистики нарахували 375706 десятин сухих сіножатей, або 8,2 \% території губернії.

Як і раніше, у цьому випадку відповідні показники у різних повітах суттєво відрізнялися. Якщо у Хорольському повіті сухих сіножатей було 46229 десятин (15,6\% усієї території повіту), то у Роменському під сіножатями знаходилося всього 11820 десятин $(5,0 \%)[10,11,12,13]$.

На розведення великої рогатої худоби особливий вплив мали два фактори - збільшення чисельності міського населення й інтенсифікація обробітку землі.

Ріст товарного землеробства, що вимагав підвищення продуктивності праці, призводив, з одного боку, до більш посиленого розведення робочої худоби, ніж продуктивної, а з іншого, вна- 
слідок розшарування на селі, - до росту поголів'я лише в заможної частини селянства, що мала тяглову силу.

Та ж частина селянських господарств, що не мала засобів, не могла забезпечити нормальних умов утримання худоби й змушена була скорочувати його поголів'я [6].

\section{БІБЛІОГРАФІЯ}

1. Бондаренко А. Ф. Труды Полтавской сельскохозяйственной опытной станции. Зоотехнический отдел / А. Ф. Бондаренко. - Полтава, 1926. - С. 33-47.

2. Вестник южно-русского животноводства. 1909. - №2.

3. Краткая историческая справка о Полтавской сельскохозяйственной опытной станции (18841923 гг.). - Полтава, 1923. - №37. - С. 24-25.

4. Нагаєвич В. М. Полтавське Товариство сільського господарства і його вплив на розвиток тваринництва кінця XIX - початку XX ст. : матеріали IX конф. молодих істориків освіти, науки і техніки України. - Київ, НААН, ДНСГБ. 2004. - C. 92-94.

5. Полтавский земский календарь на 1910 год. Издание Полтавского губернського земства. Полтава : электрич. типо-литография «Дохман», 1910. - $156 \mathrm{c}$.

6. Полтавское сельскохозяйственное общество 1865-1895 гг. - Полтава : изд-во Полт. с.-х. общества, 1897. - С. 270-282.

7. Полтавщина. Енциклопедичний довідник [за ред. А. В. Кудрицького]. - К. : Українська
Висновок. Для Полтавщини розведення великої рогатої худоби на усіх етапах історичного розвитку відігравало вкрай важливе значення. На початок XX ст. тут сформувалися передумови виникнення наукових засад розвитку галузі скотарства.

Енциклопедія, 1992. - $1022 \mathrm{c.}$

8. Рклищкий М. Хозяйственный быт казаков Золотоношского уезда в старину / М. Рклицкий // Полтавский земский календарь на 1910 год. Издание Полтавского губернского земства. - Полтава : электрич. типо-литография «Дохман», 1910. - C. 36-64.

9. Россия. Полное географическое описание нашого Отечества [под ред. В. П. Семенова]. СПб. : издание А.Ф. Девриена, 1903. - Т.VII. «Малороссия». -517 с.

10. Статистический справочникъ по Полтавской губернии на 1914 годъ. - Полтава : тип-фия т-ва печатного дђла, 1913. - Вып.VII. - C. 147-151.

11. Статистический справочникъ по Полтавской губернии на 1915 годъ. - Полтава : тип-фия т-ва печатного дђла, 1915. - Вып.VIII. - С. 148-152.

12. Статистичний справочник по Полтавскій губернії на 1918-19 рр. - Полтава: друкарня т-ва печатного діла, 1919. - Вып.ХІ. - С. 127-131.

13. Якименко М. А. Історія розвитку тваринництва Полтавщини XIX-XX ст. / М. А. Якименко, В. М. Нагаєвич. - Полтава : ПДАА РВВ, 2007. $202 \mathrm{c}$. 